\title{
The Influence of Training, Customer Orientation and Work Engagement on The Hotel Supervisor Professionalism
}

\author{
Dewi Eka Arini \\ Universitas Negeri Jakarta \\ Email: dewiekaarini@gmail.com \\ Dedi Purwana \\ Universitas Negeri Jakarta \\ Email: dpurwana@unj.ac.id \\ Muchlis R. Luddin \\ Universitas Negeri Jakarta \\ Email: muchlis-rantoni@unj.ac.id
}

\begin{abstract}
The hospitality industry has grown in size and complexity to service demands that require a higher level of skills from its personnel. Qualified personnel and skilled personnel are at the core of any profession, thus the professional status of the hotel industry should encourage to maintain the quality of employees. This study aims to determine the effect of training, customer orientation, and job engagement on the professionalism of hotel supervisors in the hotel industry in Indonesia based on the rapidly changing needs of customers in the industry. The data collected was taken from a national hotel chain totaling 49 hotels from several regions in Indonesia and taking a sampling of 219 supervisors. Customer orientation has the highest significant influence on supervisor professionalism than training and works engagement. The research provides an indepth analysis of hotel supervisor professionalism, the hotel managers need to carefully provide continuous development or supervisor through training with customer orientation context.
\end{abstract}

Keywords: Training, customer orientation, work engagement, supervisor professionalism.

Received: 21 August 2020 ;

Accepted: 30 September 2020 ;

Publish; December 2020.

\section{How to Cite:}

Arini, D.A., Purwana, D., Luddin, M.R. (2020). The Influence of Training, Customer Orientation and Work Engagement on The Hotel Supervisor Professionalism. International Journal of Human Capital Management, 4 (2), 114-124. https://doi.org/10.21009/IJHCM.04.02.10 


\section{INTRODUCTION}

The hospitality industry has grown in size and complexity to service demands that require a higher level of skill from its personnel. Based on statistical data reprocessed by the Ministry of Tourism on the room occupancy rate (TPK) of star hotels in 2018 vs 2017, it shows an increase in a room occupancy rate of 1.12 points. This shows that the hotel industry in Indonesia continues to grow and hotels must increase customer satisfaction by increasing the professionalism of all hotel employees through the involvement of all employees to achieve the goals set. The reality of professionalism in most service-based jobs and international environments has essential elements of professionalism in the form of professional knowledge, strong cultural sensitivity, customeroriented behavior, and industry knowledge, hotels tend to take a short-term approach to career development, the hotel industry needs to find ways to justify professional development costs. To ensure that employees have professionalism in accordance with the demands of the hospitality industry, it is necessary to research the factors that affect the increase in one's professionalism. The hospitality industry is faced with unprecedented tasks to meet consumer demand while providing excellent customer service.

Perceptions of professionalism that was obtained from several hotel workers from junior staffs, middle managers, and senior executives were found that there were 8 elements of professionalism, namely passion, open-mindedness to new trends, attitudes towards the team, competence and skill, professional ethics, leading by example and perfectionism (Cheng and Wong, 2014). This research was conducted on a small scale which was only attended by 42 respondents, and it is possible to expand the respondents that represent a wider population. Professionalism for the workforce is critical for the development of the tourism and hospitality industry. There is a significant effect of customer orientation on professionalism (Kyoung-Joo Lee, 2014). The limitation of this study is that it is only conducted in one city and from super deluxe hotels, it is necessary to expand the population for further research. Professionalism becomes a discursive tool for discipline, performance, and control. Focusing on securing more meaningful work and integrating dignity through activities such as caring relationships and further education for managers (Cheryl Cockburn-Wootten, 2012). The hospitality industry needed a reconceptualization of communication, an alternative practice in the workplace.

In order to adapt the hotel industry to rapid changes, human resources are considered to be one of the most important assets because the quality of human resources is determined by quality and customer satisfaction. From the results of the pre-survey which resulted in the perception of supervisors that the ability to solve problems for unsatisfied guests (57.14\%), managing unrealistic requests with the team $(55.76 \%)$, was always innovative $(61.9 \%)$.

Based on the background of the state of the hotel industry and the pre-survey conducted, this research is needed to ensure the relationship between training variables $\left(\mathrm{X}_{1}\right)$, customer orientation $\left(\mathrm{X}_{2}\right)$, and work engagement $\left(\mathrm{X}_{3}\right)$ on the professionalism of hotel supervisors $(\mathrm{Y})$. This present study aims to determine the effect of training, customer orientation, and job involvement on the professionalisme of hotel supervisor.

\section{LITERATURE REVIEW}

\section{Supervisor Professionalism}

Industry depends primarily on the skill level and professionalism of its employees. The competencies that employees must possess continue to move according to the needs, desires, and expectations of guests which keep changing. In the contemporary era, almost everyone wants to become a professional, a wide variety of jobs are now trying to achieve professionalism. According to the Indonesia Dictionary: 
A profession is a job from which you earn a living, while professionalism can be defined as being a profession or having expertise and skills due to education and training. (Badudu and Sutan, 2002).

Arens et al. (2012) define professionalism as the responsibility of individuals to behave better than simply complying with existing laws and regulations in society. Other studies have described professionalism as positively associated with innovation (Sundbo et al., 2007). Several researchers highlight the increasing importance of professionalism in the hospitality and tourism industry (Torres and Kline, 2012). Freidson stated that professionalism is related to the philosophy, beliefs, and principles of work or profession (Freidson, E., 2001) therefore it can adapt quickly in a dynamic environment, service orientation, and high workforce intensity, the hotel industry has obliged its members to embrace the highest level of professionalism (Wong and Chan, 2010) and developing hotel management into a profession (Burgess, 2010) also support professionalism as the key to achieving long-term viability and competitiveness in the industry. Lee (2014) writes that the structural professional image, firmly rooted in sociology, has analyzed the processes and conditions of professionalization, with a focus on a set of organizing principles that elevate "work" to a high level of status and privilege in society. Lee's definition of a professional is as a set of individual values, behavioral orientations, and belief systems that advance the individual's skills and occupational social status. The list of organizational principles of structural professional characteristics includes systemic knowledge (Systemic Body of Knowledge), professional association, autonomy, and code of ethics. Explicitly, individual professionalism increases productivity by helping hotels operate smoothly, which can lead to improved reputation, image, and word of mouth promotion, increased profitability, and high revenue through repeat business activities (Cheng and Wong, 2015).

Other research on the professional competence of foodservice research and development is divided into five dimensions: product knowledge and capacity, activeness, and resilience, management capacity, innovation, and change and characteristic maturity (Ko, 2012). Certain elements typical of professionalism in the context of hospitality are team-oriented, attitude, and self-control, which may be very important given the service-oriented nature of the industry's additional components lead by example and perfectionism (Cheng and Wong, 2015). Hotel supervisors who have transformational leadership behaviors are more likely to develop the ability to reduce the percentage of employees who leave their hotels (Chang and Teng, 2017).

The current model of corporate professionalization that seems to explain the successful professionalization of other jobs is not being adopted by people in the industry. While it is possible to detect elements, such as concerns with commercial practices and the need to show opportunities for knowledge creation and sharing, it is even still underdeveloped and represents propositions to potential members who are arguably, somewhat vague or invisible (Thomas and Thomas, 2013).

Supervisor, which is someone professional, flexible, polite, competent, helpful, responsible, well-groomed, efficient, patient, and knowledgeable. The duties of a supervisor based on the International Standard Classification of Occupation (ISCO) include being involved in work, training, supervising, controlling inventory purchases, controlling storage and inventory problems, overseeing general welfare, and individual behavior in institutions (ILO, 2012). They are good communicators, listeners, and team players, and they consistently display a positive attitude.

Based on these definitions, professionalism for a supervisor in the hospitality industry is someone who has personal and social skills with a set of individual values, behavioral orientation, high labor intensity, and a belief system so that they can follow the needs, wants, and expectations of guests keep changing. With dimensions taken from Cheng Simon and Alan Wong (2015), namely (a) Desire, (b) Open mind, (c) Team orientation, (d) Professional Ethics, (e) Leadership, (f) Perfection. 


\section{Training}

Training is associated with the skills that employees must acquire to assist them by working with others to achieve organizational goals and objectives (Truitt, 2011). The achievement of organizational goals and objectives related to employee productivity, to increase employee productivity, training is one of the methods often used in learning new knowledge and skills that are important for providing high-quality customer service (Shen and Tang, 2018).

One way to develop and improve the quality of employees is to provide them with useful training and development programs for the acquisition of knowledge, skills, and abilities by professionals (Sabir et al., 2014).

Training programs are stimulants needed by workers to improve their performance and abilities, which consequently increases organizational productivity (Imran, 2013). Therefore, training must be designed based on the specific needs and goals of the company. Effective training is a thoughtful intervention designed to achieve the learning needed to improve employee professionalism. There is a direct influence of managers and customers on encouraging customeroriented behavior. Therefore, in the service industry, leadership, training, and guidance programs play an important role in shaping employee attitudes and behavior (Anaza, 2012). Through training, employees will have knowledge and understanding that make work more meaningful and can psychologically maintain a level of engagement and foster a safe environment (Rana, 2015). When employees receive their organizational investment through training and development, they are more engaged (Shuck et al., 2014). The perception of training related to performance behavior suggests that personal role engagement is a stronger mediator than job engagement (Fletcher, 2015).

This training concept is a stimulant that contributes to increased work engagement and customer-oriented professionalism. With dimensions taken from Shen and Tang (2018) which consist of (a) the suitability of training materials, (b) The desire to implement training results, (c) Contribution to careers, (d) Productivity in Organizations, (e) Changes in behavior towards the organization.

\section{Work Engagement}

According to Cale (Cale et al., 2004), job engagement is a positive, satisfying, work-related state of mind that is characterized by passion, dedication, and absorption. Passion is characterized by a high level of energy and mental resilience at work, a willingness to invest effort in one's work, and persistence even in the face of adversity. Dedication refers to being strongly involved in one's work and experiencing a sense of significance, enthusiasm, inspiration, pride, and challenge. Absorption, characterized by being fully concentrated and happily engrossed in work, where time passes quickly and a person has difficulty getting away from work. Organizational support in the form of caring that can be felt by employees can create an understanding of the employee's duties which will be shown through work involvement with a higher level (Nazir and Islam, 2017).

Job engagement is a form of commitment of an employee in involving the role and concern for work both physically, knowledgeably, and emotionally. Brown (in Prihantini, 2013 and Risa Yuliana) said that job engagement refers to the degree to which a person psychologically sides with their organization and the importance of work for their self-image. Job engagement is a unique and distinct construct because it represents a more comprehensive and broader concept than other ideas such as job satisfaction, organizational commitment, or job engagement, which includes cognitive, emotional, and behavioral components related to individual role performance (Shuck, Ghosh, Zigarmi, \& Nimon, 2014). In the hospitality industry, work involvement is related to positive hotel organizational behavior following the definition of ( $\mathrm{Lu}$ et al., 2016) that job engagement is a positive working condition that improves organizational performance. Based on 
the definitions above, job engagement for supervisors is characterized by enthusiasm, dedication and absorption.

\section{Customer orientation}

By definition, customer orientation can be seen as the task of hotel management and staff (Maja and Dragomir, 2013). An active approach to customer orientation can lead to the creation of a knowledge base that helps hotel management and staff continue to learn about the perceptions and demands of new and old customers. Hotels need to have a strategy to continue to offer quality to their customers. This study concludes that Nwankwo's framework for analyzing customer orientation can apply to hotels because there is a high degree of correlation between all the determinants in the proposed framework. Nwankwo developed a framework that can show whether an organization has a high or low level of customer orientation, namely:

1. Place customers in the focus of their business activities, rather than organizational factors. Customer-oriented organizations have a clear picture of their customers, based on their target market, designing products and services (Definition).

2. Demonstrate a proactive approach to customers. In other words, they try to identify the expectations and needs of their previous customers and build their customer strategy based on that information. Customer-oriented organizations do not wait for problems to appear to start responding to them but have an understanding of their existing and potential customers before any action (Sensitivity).

3. Use formal methods and techniques to measure business performance, including market share indicators. Customer-oriented organizations do not always have estimated values for market analysis and customer complaint analysis, but rather have a formal measurement mechanism. They use measurement to get a clear indicator of whether the activities carried out have a positive effect on business performance (Measurement).

4. Work intensively to offer the expected service value to their customers. In a customeroriented organization, management and employees are fully engaged and motivated to help their customers in the best possible way, thus securing the maximum level of satisfaction (Implementation).

5. Through training, organizations can develop managers who understand the importance of customer orientation and create a customer-oriented communication environment. This is evidenced in the Swiss hotel sector which can "put the interests of customers first" to achieve long-term profitability (Tajeddini and Trueman, 2012). Customer orientation was found to have a significant and positive influence on the development of new services and this study highlights the importance of managerial emphasis on creating a customeroriented environment that is conducive to innovative activities (Tajeddini, 2011).

6. Customer orientation is a strategic execution for employees on service and customers to build sustainable trust for their relationship and can also be defined as a market-oriented attitude and proactive activities to provide excellent service (Kang and Kim, 2015). Employees with customer orientation, focus on serving customers to meet their expectations and use a problem-solving approach to handling their requests and problems (Karatepe, 2013). Customer orientation and service innovation are significantly related (Tang, 2014). Customer orientation is an attitude to build sustainable trust proactively to provide excellent service to customers to achieve long-term profitability for the hotel. With the adoption of dimensions taken from Ursula Grissmann, namely (a) Sensitivity, (b) Measurement), (c) Implementation.

Furthermore, the proposed hypotheses are as follows:

1. Training has a direct positive effect on supervisor professionalism.

2. Customer orientation has a direct positive effect on supervisor professionalism. 
3. Work engagement has a direct positive effect on supervisor professionalism.

4. Training has a direct positive effect on customer orientation

5. Training has a direct positive effect on work engagement

6. Customer orientation has a direct positive effect on work engagement

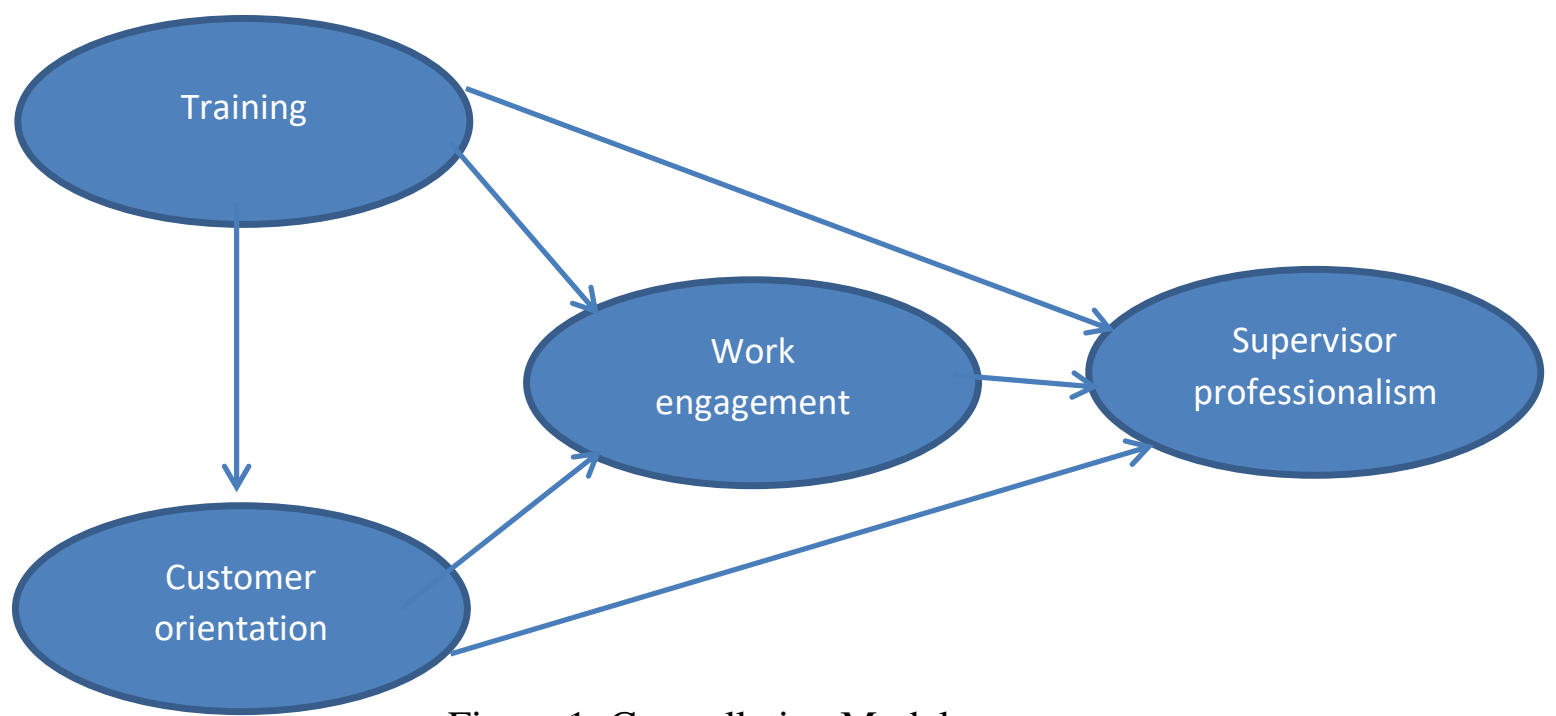

Figure 1. Constellation Model

\section{RESEARCH METHOD}

This study used quantitative approach with survey method to understand more deeply the problems that exist in the problem formulation that has been described in this study. The data were collected from 49 hotels in Indonesia with a sample of 219 supervisors as respondents. However, the effective questionnaires used for analysis are 214 questionnaires. This study used Structural Equation Modelling (SEM) for the data analysis.

A questionnaire was designed to ask hotel supervisors dor their perception on a range of proffesionalism including training, customer orientations and work engagement. This information was collected using a five-point scale $(1=$ strongly disagree to $5=$ strongly agree $)$ in response to statement about these variables. The questionnaire was pre-tested using two academics in order to ensure that the survey content and measurement scales were clear, valid and appropriate. The Data were collected through link of the questionnaire using google form, by contacting each General Manager and seeking permission to collect data. Data for training were collected using the training orientation scale adopted from Shen J and Tang C, 2018, the scale consists of 20 items. Data on customer orientation were collected using the customer orientation scale adopted from Nwanko (2007) and Grissemann (2013). Data for work engagement were collected using the work engagement scale designed by Cale, Schaufeli and Bakker, 2004, the scale consist of 16 items. Data for proffessionalism were collected using the professionalism orientation scale adopted from S.Cheng and Wong, 2015, the scale consist of 48 items.

\section{Result}

\section{RESULT AND DISCUSSION}

The result analysis of the Complete Structural Model (Full Model) has met the evaluation criteria of a model, which are CMIN/DF: 1.006, CFI: 0.999, GFI: 0.820, RMSEA: 0.005. The full model were shown as follows: 


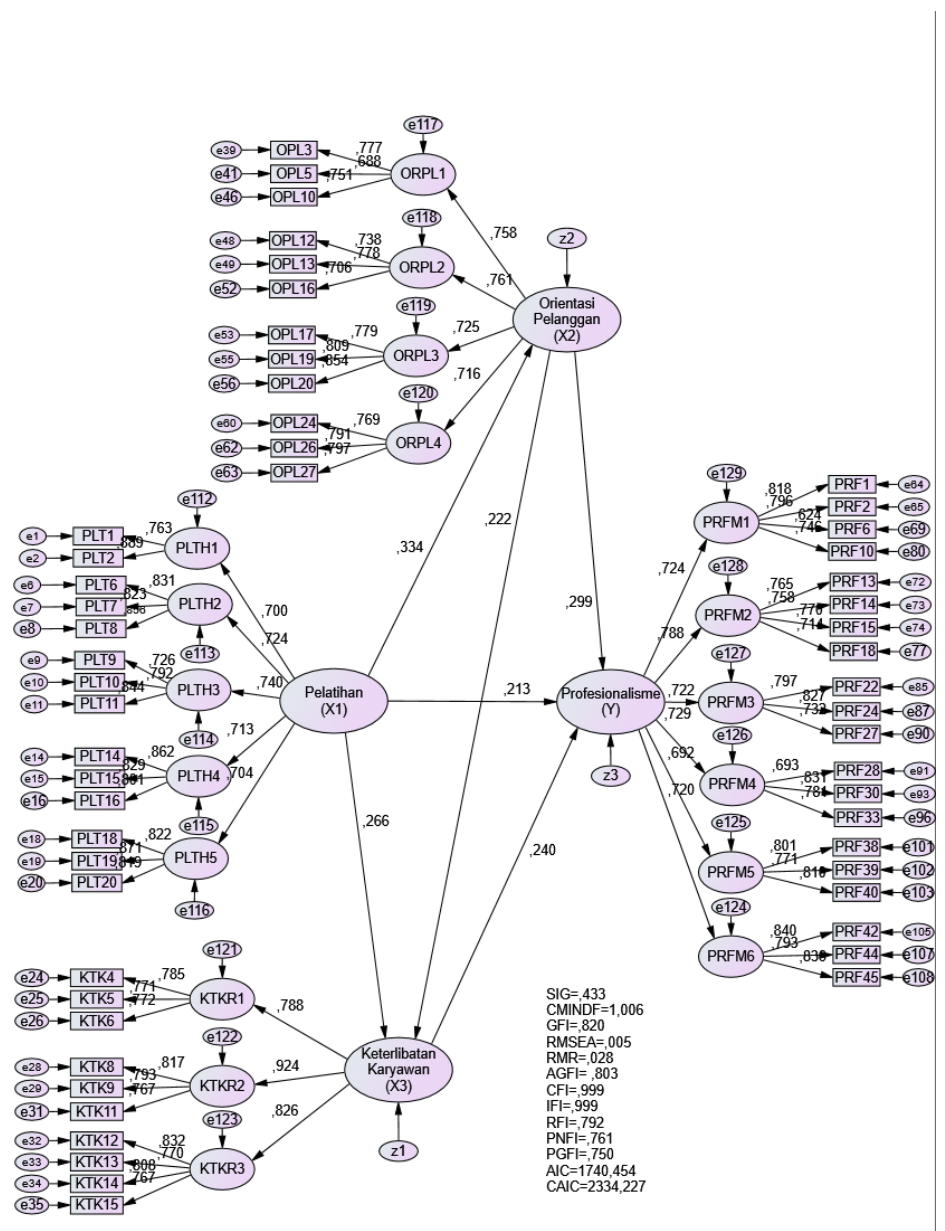

Figure 2. SEM Full Model

H1. There is a significant positive direct effect of Training $\left(X_{1}\right)$ on Professionalism $(Y)$

From the results of the direct effect of Training $\left(\mathrm{X}_{1}\right)$ on Professionalism (Y), the path coefficient is 0.213 and $\mathrm{CR}$ is $2.351 \geq 1.96$, which means there is a significant positive direct effect of training $\left(\mathrm{X}_{1}\right)$ on professionalism $(\mathrm{Y})$.

\section{H2. There is a significant positive direct effect of Customer Orientation $\left(\mathrm{X}_{2}\right)$ on Professionalism (Y)}

Based on the calculation result of the direct effect of Customer Orientation $\left(\mathrm{X}_{2}\right)$ on Professionalism (Y), the path coefficient is 0.299 and CR is $3.160 \geq 1.96$, it means that there is a significant positive direct effect Customer Orientation $\left(\mathrm{X}_{2}\right)$ on Professionalism $(\mathrm{Y})$.

H3. There is a significant positive direct effect of work engagement $\left(\mathrm{X}_{3}\right)$ on Professionalism (Y)

Based on the result of it was found a direct effect of work engagement $\left(\mathrm{X}_{3}\right)$ on Professionalism (Y) with path coefficient of 0.240 and $C R$ is $2.74 \geq 1.96$. It means that there is a significant positive direct effect work engagement $\left(\mathrm{X}_{3}\right)$ on Professionalism $(\mathrm{Y})$.

H4. There is a significant positive direct effect of training $\left(X_{1}\right)$ on customer orientation $\left(X_{2}\right)$

Based on the results, the direct effect of training $\left(\mathrm{X}_{1}\right)$ on customer orientation $\left(\mathrm{X}_{2}\right)$ with the path coefficient value of 0.334 and $\mathrm{CR}$ is $3,367 \geq 1.96$, it can be interpreted that there is a significant positive direct effect training $\left(\mathrm{X}_{1}\right)$ on Customer Orientation $\left(\mathrm{X}_{2}\right)$ 


\section{H5. There is a significant positive direct effect of training $\left(X_{1}\right)$ on work engagement $\left(X_{3}\right)$}

The results has found that there is a direct effect of training $\left(\mathrm{X}_{1}\right)$ on work engagement $\left(\mathrm{X}_{3}\right)$ with the path coefficient of 0.266 and $\mathrm{CR}$ is $2.7999 \mathrm{e} \geq 1.96$. This can be interpreted that there is a significant positive direct effect training $\left(\mathrm{X}_{1}\right)$ on work engagement $\left(\mathrm{X}_{3}\right)$

\section{H6. There is a significant positive direct effect of customer orientation $\left(\mathrm{X}_{2}\right)$ on work engagement $\left(\mathbf{X}_{3}\right)$}

The results has found that there is a direct effect of customer orientation $\left(\mathrm{X}_{2}\right)$ on work engagement $\left(\mathrm{X}_{3}\right)$ with path coefficient of 0.222 and $\mathrm{CR}$ is $2.384 \geq 1.96$. This can be means that there is a significant positive direct effect customer orientation $\left(\mathrm{X}_{2}\right)$ on work engagement $\left(\mathrm{X}_{3}\right)$

\section{Discussion}

The results of the analysis of the first hypothesis have found that training $\left(\mathrm{X}_{1}\right)$ has a positive direct effect on professionalism (Y), it means that the better the training will cause professionalism to increase and vice versa. The results of this study also strengthen the findings of the research (Ko Weh-Hwa, 2012; Torres and Kline, 2013) which states that active participation in training is a way to help achieve and enrich professionalism that benefits the acquisition of knowledge, skills, and abilities (Sabir et al., 2014) to increase organizational productivity (Imran, 2013). It can be said that the desire to apply the results of training in the workplace as a contribution towards a career as a supervisor is one component to continuously improve professionalism as a hotel supervisor.

The second hypothesis has found that Customer Orientation $\left(\mathrm{X}_{2}\right)$ has a direct positive effect on Professionalism (Y). It can be interpreted that the higher the Customer Orientation $\left(\mathrm{X}_{2}\right)$ will cause an increase in Professionalism. It is supported by the results of previous studies related to the professionalism section including service innovation (Umasuthan, Hamsanandini and OunJoung Park, 2018, Tang W Ta, 2014, Tajeddini. Kayhan \& Myfanwy Trueman, 2012). It can be concluded that sensitivity to customer needs and then implementing them in work is a variable that increases professionalism as a hotel supervisor.

The third hypothesis analysis has found that work engagement $\left(\mathrm{X}_{3}\right)$ has a positive direct effect on Professionalism (Y), which means that the better Work Engagement $\left(\mathrm{X}_{1}\right)$ will cause an increase in Professionalism $\left(\mathrm{X}_{3}\right)$. It is supported by the results of previous studies that increased work involvement can be associated with increased professionalism including high adaptability, job satisfaction so that it has an impact on career commitment (Alfes et al., 2013; Lu et al., 2016; Barnes and Collier, 2014). It can be concluded that job engagement has a positive effect on the professionalism of hotel supervisors. This means that dedication to work, determination and enthusiasm when working in the workplace are important components to continuously improve professionalism with support from management, colleagues and even customers.

The fourth hypothesis analysis has found that training $\left(X_{1}\right)$ has a positive direct effect on Customer Orientation (X2), which means that the better training (X1) will cause an increase in customer orientation $\left(\mathrm{X}_{2}\right)$. This positive effect shows that the higher the impact of the training that is attended by hotel supervisors, the higher the customer orientation of the hotel supervisors will be. This is in line with previous research, namely with a strong customer orientation, professional employees consistently learn and acquire new skills and expertise and develop an ability to analyze customer problems and solve them by adapting various services (Lee, 2014).

The results of the fifth hypothesis analysis has found that training $\left(\mathrm{X}_{1}\right)$ has a positive direct effect on work engagement $\left(\mathrm{X}_{3}\right)$, which means that the better training $\left(\mathrm{X}_{1}\right)$ will cause an increase in work engagement $\left(\mathrm{X}_{3}\right)$. This is in line with previous research which shows that training satisfaction is positively related significantly to the level of employee work engagement (Mumtaz Ali Memon, Rohani Salleh, Muhamed Noor Rosli Baharom 2016) which was carried out on professionals from the oil and gas industry, so it is a novelty in this research. is done in a different 
industry, namely hospitality. Other research states that the professional development of trainees allows them to support greater work autonomy to increase work engagement (Paniotis Zis, Anagnostopulos, Artemios K. Aremiadis, 2016).

The results of the sixth hypothesis analysis has found that customer orientation $\left(\mathrm{X}_{2}\right)$ has a positive direct effect on work engagement $\left(\mathrm{X}_{3}\right)$, which means that the better customer orientation $\left(\mathrm{X}_{2}\right)$ will cause an increase in work engagement $\left(\mathrm{X}_{3}\right)$. This positive effect indicates that the higher the customer orientation of the hotel supervisor, the higher the customer orientation of the hotel supervisor, the higher the work engagement of the hotel supervisor. This is in line with the results of previous studies that found a positive and statistically significant relationship between customer orientation and work engagement (Rutherford, NA.A Brian, 2012). The study at a retail bank and insurance company also found that there is a significant relationship between customer orientation and work engagement (Jay Jaewon Yoo and Todd H. Arnold, 2014) Including employees' perceptions of consumer pleasure has become something strong and has a significant relationship to work engagement (Donald C Barnes, Joel E. Collier, Stacey Robinson, 2014). This finding contributes in establishing the relationships among four variables in the context of proffessionalism of the hospitality sektor in national hotel chain in Indonesia.

\section{CONCLUSION}

In conclusion, this study has found that training has an impact on supervisor proAfessionalism, which means that better training will increase supervisor professionalism. Customer orientation has an impact on supervisor professionalism, which means that increased customer orientation will increase supervisor professionalism. Work engagement has an impact on supervisor professionalism, which means that employees that engaged in their work will lead to better supervisor professionalism. Training has an impact on customer orientation, which means that better training will bring to better customer orientation. Training has an impact on work engagement, which means that better training will encourage employees to be more engaged in their work. Customer orientation has an impact on work engagement, which means that better customer orientation will boost employees to be more engaged in their work.

\section{Recommendation}

This study provides several recommendations which are expected to be useful advice for several parties:

1. Conduct customer-oriented seminars, workshops, and training to encourage increased professionalism in the open mind dimension and the dimension of professional ethics. The themes of seminars, workshops, training include the themes of accessing the industry code of ethics, trends in the lifestyle of tourists who come to the city where the hotel is located, or the use of electronic systems on a job as a supervisor.

2. Activities related to the work involvement of supervisors need to be maintained in accordance with the needs and characteristics of each hotel, according to the research results, the spiritual dimension needs to be improved again to encourage other dimensions of work involvement.

3. The use of online information for customers' feedback can use customer surveys provided both in-house or internationally to develop and improve tasks as supervisors.

\section{REFERENCES}

Alfes, K., Shantz, A. D., Truss, C., and Soane, E. C. (2013). The link between perceived human resource management practices, engagement and employee behaviour: a moderated mediation model. The International Journal of Human Resource Management, 24 (October 2017), 330-351. https://doi.org/10.1080/09585192.2012.679950. 
Anaza, N. A. and B. R. (2012). Article information: How Organizational and Employee-customer identification, and customer orientation affect job engagement. Journal of Service Managememt, 23(5): 616-619.

Arens, A. A., Elder, R. J., and Mark, B. (2012). Auditing and assurance services: an integrated approach. Boston: Prentice Hall.

Badudu dan Sutan (2002). Kamus Umum Bahasa Indonesia. Jakarta: Pustaka Sinar Harapan.

Barnes, D. C., Collier, J. E., Ponder, N., Williams, Z., Barnes, D. C., Collier, J. E., and Williams, Z. (2013). Investigating the Employees' Perspective of Customer Delight. Journal of Personal Selling and Sales Management, XXXIII no. (December 2014): 91-104. https://doi.org/10.2753/PSS0885-3134330108.

Burgess, C. (2010). Article information: Are hotel managers becoming more professional: the case of hotel financial controllers.

Cale, W. O. R. K. E. N. S., Schaufeli, W., and Bakker, A. (2004). U w e s.

Chang, J., and Teng, C. (2017). International Journal of Hospitality Management Intrinsic or extrinsic motivations for hospitality employees' creativity: The moderating role of organization-level regulatory focus. International Journal of Hospitality Management, 60: 133-141. https://doi.org/10.1016/j.ijhm.2016.10.003.

Cheng, S., and Wong, A. (2015). International Journal of Hospitality Management Professionalism : A contemporary interpretation in hospitality industry context. International Journal of Hospitality Management, 50: 122-133.

Fletcher, L. (2015). Training perceptions, engagement, and performance: comparing work engagement and personal role engagement, 8868 (October). https://doi.org/10.1080/13678868.2015.1067855.

Freidson, E. (2001). Professionalism: The Third Logic on practice of knowledge, University of Chicago Press.

Imran, A. (2013). The Effect of Training on Employee Performance. European Journal of Business and Management, 5(4): 137-147.

Kang, J., and Kim, J. (2015). The followership of hotel employees and the relationship between occupational burnout, job stress, and customer orientation: Targeting the hotel service providers at luxury hotels. https://doi.org/10.1177/1467358415610374.

Karatepe, O. M. (2013). International Journal of Hospitality Management High-performance work practices and hotel employee performance: The mediation of work engagement. International $\begin{array}{llll}\text { Journal of Hospitality } & \text { Management, }\end{array}$ https://doi.org/10.1016/j.ijhm.2012.05.003.

Ko Wen-Hwa (2012), Journal of Hospitality, Leisure, Sport \& Tourism Educationn11, A Study of the relationships among effective learning, professional competence, and learning performance in culinary field. p. 12-20. https://doi.org/10.1016/j.jhlste.2012.02.010.

Lee, K. (2014). International Journal of Hospitality Management Attitudinal dimensions of professionalism and service quality efficacy of frontline employees in hotels. International Journal of Hospitality Management, 41: 140-148. https://doi.org/10.1016/j.ijhm.2014.05.015

Lu, L., Cheng, A., Lu, C., Gursoy, D., Neale, N. R., Lu, Neale, N. R. (2016). Work engagement , job satisfaction, and A comparison between supervisors and. International Journal of Contemporary Hospitality Management, 28: 737-761. https://doi.org/10.1108/IJCHM-072014-0360.

Maja, C., and Dragomir, D. S. I. (2013). Measurement Framework for Analyzing Customer: 493502.

Nazir, O., and Islam, J. U. (2017). Enhancing organizational commitment and employee performance through employee engagement an empirical check. https://doi.org/10.1108/SAJBS-04-2016-0036.

Panagiotis Zis, Fotios Anagnostopulos, Artemios K. Aremiadis, Risidency Training: Work 
engagement during neurology training, American Academy of Neurology, 2016. First published August 1, 2016, DOI: https://doi.org/10.1212/WNL.0000000000002911

Rana, S. (2015). Human Resource Development International High-involvement work practices and employee engagement, (April): 37-41. https://doi.org/10.1080/13678868.2014.1003698.

Sabir, R. I., Akhtar, N., Ali, F., Bukhari, S., Nasir, J., and Ahmed, W. (2014). Impact of Training on Productivity of Employees: A Case Study of Electricity Supply Company in Pakistan.

Shen, J., and Tang, C. (2018). How does training improve customer service quality? The roles of transfer of training and job satisfaction. European Management Journal: 1-9. https://doi.org/10.1016/j.emj.2018.02.002.

Shuck, B., Twyford, D., Jr, T. G. R., and Shuck, A. (2014). Human Resource Development Practices and Employee Engagement : Examining the Connection With Employee Turnover Intentions, 25(2): 239-270. https://doi.org/10.1002/hrdq.

Sujarweni VW (2015), Metodologi Penelitian Bisnis dan Ekonomi. Pustaka baru press, Yogyakarta.

Sundbo, J., Orfila-sintes, F., and Sørensen, F. (2007). The innovative behaviour of tourism firms - Comparative studies of Denmark and Spain. Research Policy, 36: 88-106. https://doi.org/10.1016/j.respol.2006.08.004.

Tajeddini, K. (2011). Journal of Hospitality \& Tourism Research. Customer Orientation, Learning Orientation, and New Service Development: An Empirical Investigation of the Swiss Hotel Industry, https://doi.org/10.1177/1096348010380599

Tajeddini, K., and Trueman, M. (2012). International Journal of Hospitality Management Managing Swiss Hospitality: How cultural antecedents of innovation and customer-oriented value systems can influence performance in the hotel industry. International Journal of Hospitality Management, 31(4): 1119-1129. https://doi.org/10.1016/j.ijhm.2012.01.009.

Tang, T. (2014). International Journal of Hospitality Management Becoming an ambidextrous hotel: The role of customer orientation. International Journal of Hospitality Management, 39: 1-10. https://doi.org/10.1016/j.ijhm.2014.01.008.

Thomas, R., and Thomas, H. (2013). What are the prospects for professionalizing event management in the UK ? TMP, 6:8-14. https://doi.org/10.1016/j.tmp.2012.11.005.

Torres, E. N., and Kline, S. (2012). From customer satisfaction to customer delight Creating a new standard of service for the hotel industry. https://doi.org/10.1108/IJCHM-Dec-2011-0228.

Truitt, D. L. (2011). The Effect of Training and Development on Employee Attitude as it Relates to Training and Work Proficiency. https://doi.org/10.1177/2158244011433338.

Umasuthan, H., Park, O., Umasuthan, H., \& Park, O. (2018). The challenges faced by hotel service industry in Sri Lanka The challenges faced by hotel service industry in Sri Lanka. International Journal of Tourism Sciences, 00(00), 1-12. https://doi.org/10.1080/15980634.2018.1471879

Wong, A., and Chan, A. (2010). International Journal of Hospitality Management Understanding the leadership perceptions of staff in China' $s$ hotel industry: Integrating the macro- and micro-aspects of leadership contexts. International Journal of Hospitality Management, 29(3): 437-447. https://doi.org/10.1016/j.ijhm.2010.01.003. 